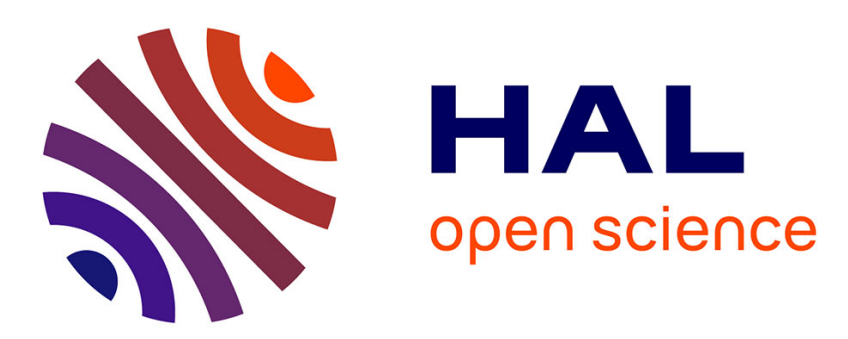

\title{
Women's participation in African peace negotiations: cooperating with the UN agencies in Burundi and Liberia
}

Marie Saiget

\section{- To cite this version:}

Marie Saiget. Women's participation in African peace negotiations: cooperating with the UN agencies in Burundi and Liberia. Peacebuilding, 2016, 4 (1), pp.28-40. 10.1080/21647259.2015.1099727 . hal02558008

\section{HAL Id: hal-02558008 \\ https://hal.univ-lille.fr/hal-02558008}

Submitted on 29 Apr 2020

HAL is a multi-disciplinary open access archive for the deposit and dissemination of scientific research documents, whether they are published or not. The documents may come from teaching and research institutions in France or abroad, or from public or private research centers.
L'archive ouverte pluridisciplinaire HAL, est destinée au dépôt et à la diffusion de documents scientifiques de niveau recherche, publiés ou non, émanant des établissements d'enseignement et de recherche français ou étrangers, des laboratoires publics ou privés. 


\title{
Women's participation in African peace negotiations: cooperating with the UN agencies in Burundi and Liberia
}

\author{
Marie Saiget
}

\section{Introduction}

This article examines women's participation in peace negotiations in Liberia and Burundi. In so doing, it aims to contribute new insights to the study of women's role in post-conflict societies, a field hitherto characterized by excessively descriptive and normative approaches. ${ }^{1}$ I argue that cooperation ${ }^{2}$ between women ${ }^{3}$ and UN agencies produces a 'parallel' form of diplomacy via the range of practices employed by women alongside official and formal peace talks. Despite their unofficial character, these practices nevertheless play a significant role in framing the course of peace negotiations.

According to the Oxford English Dictionary, 'to participate' is not only 'the action or fact of having or forming part of something', it is also the 'sharing [of] something' (identity/ies and ideas) that motivates individual or group participation. An examination of women's participation thus invites us to think about women's concrete experiences and trajectories in peace negotiations as well as the ways in which they may (or may not) have set about building a common social and political identity as women. Negotiation is a social and indeterminate process. It is also, according to William Zartman, a process of 'reducing complexity' to produce an outcome that is satisfactory to all parties involved. ${ }^{4}$ These definitions equip one to study continuity and change and thus to consider the impact of various considerations on women's participation in peace negotiations.

These considerations include diverse historical and normative contexts, the contribution of particular places, rules and scales of action and the interaction between various actors ${ }^{5}-$ in the present case, that between UN agencies and women's movements. Critical research on peacebuilding gives us incentives to take 'local relational and contextual aspects' into account. ${ }^{6}$ On the one hand, the 'local' may refer to the 'space where cooperation is built, made and remade

\footnotetext{
${ }^{1}$ For an introduction see Sanam Naraghi Anderlini, Women Building Peace: What They Do, Why It Matters (Boulder; London: Lynne Rienner Pub., 2007); Natalie Florea Hudson, Gender, Human Security and the United Nations: Security Language as a Political Framework for Women, 1 vol. (London; New York: Routledge, 2010); Inger Skjelsbæk, Dan Smith, and International Peace Research Institute, eds., Gender, Peace and Conflict (London; Thousand Oaks; New Delhi: SAGE Publications, 2001); Funmi Olonisakin, Karen Barnes, and Eka Ikpe, eds., Women, Peace and Security: Translating Policy into Practice (London; New York: Routledge, 2011). 2 Defined by William Zartman as 'a situation where parties agree to work together to produce new gains for each of the participants unavailable to them by unilateral action, at some cost'. William Zartman and Saadia Touval, ed., International Cooperation: The Extents and Limits of Multilateralism (Cambridge: Cambridge University Press, 2010), 1.

${ }^{3}$ In this paper, I use the term 'women' for convenient reasons, not as a fixed category. Thus, I try to give details about who these women are as well as their social origins (whether drawn from the elite or the 'invisible' women of mass movements).

${ }^{4}$ Ira William Zartman, Processes of International Negotiation Project and International Institute for Applied Systems Analysis, eds.., International Multilateral Negotiation: Approaches to the Management of Complexity (San Francisco: Jossey-Bass, 1994), 4-6.

${ }^{5}$ Franck Petiteville and Delphine Placidi, Négociations internationales [International negotiations] (Paris: Les presses de Sciences Po, 2013).

${ }^{6}$ David Chandler, 'Peacebuilding and the Politics of Non-Linearity: Rethinking "Hidden" Agency and

"Resistance", Peacebuilding 1, n 1 (2013), 20-21.
} 
by various actors with different inputs and capacities' as the editors of this special issue state. Similar to this view, Oliver Richmond and Audra Mitchell insist on the concept of the 'everyday' as a 'space [which] is co-created and shared by local and international actors, and is thus hybrid in itself. ${ }^{7}$ On the other hand, it can refer to a particular type of actor, often assimilated with 'societal'. As I show in this article, discussions of what constitutes the 'local' should be broadened to include, not just descriptions of women's religious, ethnic, social and political identities, but also the evolution of conflictual and/or cooperative relationships between them.

To explore these different dimensions, this article focuses on the cases of Liberia and Burundi. My aim is less to identify variables from these cases rather than to draw common social mechanisms and singular trajectories of cooperation. Over the past twenty years, both African countries have been marked by violent civil wars and international peace negotiations in which women took part. In Liberia, the first armed conflict took place between 1989 and 1997. The Abuja II Peace Accord of 1996 brought a fragile peace, elections and, in July 1997, a new government headed by President Charles Taylor. But violence broke out in 1997-98 and, between 2000 and 2003, fighting escalated between government troops and members of Liberians United for Reconciliation and Democracy (LURD). In early 2003, a new faction, the Movement for Democracy in Liberia (MODEL), became involved in the conflict, which was to continue until the signing of the Comprehensive Peace Agreement of 18 August 2003 in Accra, Ghana. ${ }^{8}$ The peace agreement followed intensive behind the scenes negotiations in Akosombo and official peace talks in Accra, which were facilitated by mediator Abdulsalami Abubakar, the former Nigerian Head of State and General.

In Burundi, a political crisis accompanied by mass violence broke out shortly after the assassination of the country's first democratically elected president, Melchior Ndadaye, in 1993. The armed conflict continued long after the Arusha Peace and Reconciliation Agreement for Burundi was signed on 28 August 2000, with the ceasefire ending the last rebellion (PALIPEHUTU-FNL) only signed in 2006. Neighbouring states initiated the Burundi peace process and imposed an embargo (Oct. 1996 - Jan. 1999) following the coup led by Major Pierre Buyoya. A multitude of different actors with competing visions of what the peace should look like took part in the negotiations, which were marked by a proliferation of non-state organizations and consultants as mediators. As in Liberia, regional political leaders facilitated the negotiation. In December 1999, Nelson Mandela replaced retired Tanzanian President Julius Nyerere as international mediator. ${ }^{9}$

In both Liberia and Burundi, women participated in peace negotiation as 'representatives of women's civil society with an observer role', which is 'one of the most sought-after forms of engagement by women in peace talks'. ${ }^{10}$ The international community sees these two

\footnotetext{
7 Oliver Richmond and Audra Mitchell, Hybrid Forms of Peace: From Everyday Agency to Post-Liberalism (Basingstoke: Palgrave MacMillan, 2012), 13. They link this cocreation with everyday agency and resistance, a normative discussion I do not include in my article, which is focused on the concrete forms of cooperation and its effects on the ways women participate in peace negotiations.

${ }^{8}$ African Women and Peace Support Group, Liberian Women Peacemakers: Fighting for the Right to Be Seen, Heard and Counted (Trenton, NJ: Africa World Press, 2004).

${ }^{9}$ On Burundian peace negotiations, see Patricia Daley, 'The Burundi Peace Negotiations: An African Experience of Peace-making', Review of African Political Economy 34, nº 112 (June 2007), 333-52; Fabienne Hara, 'Chapter 7: Burundi. A Case of Parallel Diplomacy' in Chester A. Crocker, Fen Osler Hampson and Pamela R. Aall, Herding Cats: Multiparty Mediation in a Complex World (Washington, D.C.: United States Institute of Peace Press, 1999), 139-159.

${ }^{10}$ UNIFEM. Women's Participation in Peace Negotiations: Connections between Presence and Influence. New York: UNIFEM, August 2010, 7.
} 
countries as good examples of this form of participation, a best practice ${ }^{11}$ promoted in the broader context of Security Council Resolution 1325 (2000). ${ }^{12}$ In the case of the Liberian peace negotiation, a delegation of eight women from the Liberian branch of the Mano River Women's Peace Network and the Liberian Women in Peacebuilding Program (WIPNET), led by Leymah Gbowee, ${ }^{13}$ participated in the 2003 peace talks as official observers. In Burundian peace negotiations, seven women were granted observer status in $2000 .{ }^{14}$ Operating in Burundi and Liberia, several international actors specializing in gender and women have held important roles. These include the international non-governmental organizations (NGOs) International Alert, Femmes Afrique Solidarité (FAS) and Search for Common Ground as well as several United Nations (UN) agencies, including UNIFEM/UN Women, the United Nations High Commissioner for Refugees (UNHCR) and the United Nations Development Fund (UNDP). For the purposes of the present article and because they took a leading role in addressing these issues in peace negotiations, I will mainly focus on UN agencies.

Yet, though women were present, ${ }^{15}$ never were they officially recognized as full participants. Rather, they were observers who lobbied formal negotiations or led parallel conferences. Given this outsiders' position, how do women's movements and delegations, in cooperation with UN agencies, shape the structure and dynamics of peace negotiations and influence their outcome? How do formal peace operation structures interact with informal local structures? ${ }^{16}$ On what basis do women and the parties to negotiation justify their participation and, in turn, how does this participation transform social and political identities? Drawing upon fieldwork conducted in Burundi from 2012 to $2014^{17}$ as well as an examination of United Nations and NGO reports, the present article considers the ambiguous and blurred relations between formal and informal, official and unofficial structures and practices as well as those between the local and international levels and social/societal and political actors.

The first section makes the case for approaching the support given to women's participation in peace negotiations as a circulatory and interactional process. Along this process, I show that international support to women's participation to peace negotiations take different forms depending on the context and the scales to which it is mobilised by women's movements. The second section argues that the manner in which women participate in peace negotiations sheds light on the interactions (rather than the opposition) between formal and informal, official and unofficial practices. This 'parallel' diplomacy contributes to changing the dynamics but not the structure of negotiations. In conclusion, I argue that their participation primarily impacts

\footnotetext{
11 Words or expressions borrowed from the terminology of international organisations are italicised.

12 The resolution reaffirms 'the important role of women in the prevention and resolution of conflicts and in peacebuilding' and stresses 'the importance of their equal and full involvement in all efforts for the maintenance and promotion of peace and security'. United Nations Security Council, Resolution 1325 'Women, Peace and Security’, 2000, S/RES/1325 http://www.un.org/events/res_1325e.pdf (consulted 29 July 2013).

${ }^{13}$ Leymah Gbowee was the leader of the women's mass movement, WIPNET, and later spokeswoman and leader of the Women of Liberia Mass Action for Peace. In June 2003, she led a delegation of women to Ghana. She received many awards for her work in peace, including the Nobel Peace Prize (conjointly with Ellen Johnson Sirleaf and Tawakkul Karman).

14 UNIFEM. Women's Participation, 7-8.

15 As in the title of the 2010 UNIFEM report on women's participation in peace negotiations, Women's Participation in Peace Negotiations: Connections between Presence and Influence. Mere presence, however, does not necessarily translate into influence or an effective role in peace negotiations.

${ }^{16}$ Olonisakin, Barnes and Ikpe, Women, peace and security, 225.

17 I conducted 18 in-depth interviews with Burundian women who participated in the Arusha peace process as well as with UN and NGOs employees. One should be particularly careful with this data, especially with individual social representations, as people interviewed often tend to enhance their particular role. To counterbalance this potential bias, I also drew upon archival data from the UN and NGOs as well as videos and articles in the press, especially for the Liberian case.
} 
the dynamics of identity politics rather than the (limited) direct outcomes of peace accords. In both cases, and despite contextualised effects, women were able to (re)open the debate on their political contributions to the construction of post-war political and social institutions.

\section{Promoting women's participation in peace negotiations: a circulatory and interactional process}

In this section, I examine cooperation between UN agencies and women's movements in promoting women's participation in peace negotiations. UN support, I contend, transforms women's movements. Women's experiences, in their turn, change UN practices. As Roger Mac Ginty argues, the study of 'hybrid' social practices ${ }^{18}$ - in the present instance, women's movements - challenges such categories as the 'local' and the 'international'.

\section{Contextualizing the 'hybridization' of women's peace movements}

To this end, I will address three different contexts, all of them familiar from the work of Gary Goertz: ${ }^{19}$ temporality, scales and norms. These contexts act as constraints upon and resources for actors' strategies.

The present study should first be placed in its temporal context. International programmes in Liberia and Burundi have built upon women's rights movements promoting norms of equal participation in decision-making, particularly in what concerns peace processes. In Liberia, women's movements, such as the Liberian Women Initiative (LWI), which provided a platform for women's participation in Accra, had already emerged in the course of the first civil war. In the case of Burundi, grassroots women's activities started shortly after the onset of the 1993 crisis in Bujumbura, the ethnically divided capital city of Burundi. Urban, educated women created the group of women's associations and NGOs in Burundi (CAFOB) ${ }^{20}$ with support from the Canadian NGO, CECI (Centre for International Study and Cooperation). Several turning points are also worth identifying. The embargo that was in 1996 imposed on Burundi by regional powers acted as a 'fillip' 21 on elite women, prompting them to organize and lobby against sanctions. In Liberia, where fighting between government forces, LURD and MODEL had escalated over the course of 2003, there were calls for 'more forceful, more dramatic action'. ${ }^{22}$ The Muslim Women of peace network joined forces with the Christian women of WIPNET in a new organization, Women of Liberia Mass Action for Peace. They also developed a relationship with refugee camps for Liberian women. The same year, women's movements presented a position statement to the Liberian government. These turning points were embedded in a very localized periodicity characterized by overlapping trends and various trajectories. In the case of Burundi, elite women's movements represented a practice run for women's participation in the peace process (they came to an end when women were finally present in Arusha). In Liberia, the women's mass movement was coordinated by women leaders in Accra, who stepped up the movement's action in 2003, the year of the peace negotiation.

\footnotetext{
${ }^{18}$ He defines the concept of 'hybridity' as 'the composite forms of social thinking and practice that emerge as the result of the interaction of different groups, practices, and worldviews.' In Roger Mac Ginty, International Peacebuilding and Local Resistance: Hybrid Forms of Peace (Basingstoke: Palgrave Macmillan, 2011 ), 8.

${ }^{19}$ Gary Goertz, Contexts of International Politics (New York: Cambridge University Press, 1994), 4-5. Gary Goertz discusses 'three substantive contexts that influence state's behavior: the structure of the international system, the historical context of behaviour and the normative environment.'

20 This women's network began with 7 women's organisations; it now includes 52 of them. It is the most important and well-known women's network in Burundi and its leaders played a crucial role in promoting women's participation in the Arusha peace negotiations.

${ }^{21}$ Catherine Mabobori (President of CAFOB in the 1990s and that group's delegate in Arusha), in 'Place aux femmes', Spécial Cinquantenaire, Magazine du CAFOB, (Bujumbura: PNUD Burundi, July 2012) quote at p. 44. ${ }^{22}$ Leymah Gbowee, interview, Pray the Devil Back to Hell. Directed by Gini Reticker. US: Balcony Releasing, 2008. https://archive.org/details/PrayTheDevilBackToHell (accessed July 5th, 2013).
} 
Though the second Liberian civil war put a break on women's movements, women continued to be involved in peace activism and extended it at the regional level. In both cases, international actors spread their support over time and focused their attention on peace talks. They did not create women's movements but rather helped structure them into large networks, increasing the visibility of their activities.

The second context regards scales of action. These operated as both constraints on and resources for the strategies of women's movements. To understand the structuration of women's movements, one must particularly attend to the sub-regional scale. In the case of Burundi, women's movements acted at the national level to mobilize regional actors against the embargo and lobby for the integration of women into the peace process. They targeted powerful women such as Spéciosa Kazibwe, the Ugandan Vice President and President of the Organization of African Unity's (OUA) Women's Committee on Peace, and Aloysia Inyumba, the Rwandan Minister for the Family and the Promotion of Women. Moreover, a group of 67 women led by Sabine Sabimbona ${ }^{23}$ took advantage of regional meetings to expose the disastrous consequences of the embargo on vulnerable people, especially women and children. In Liberia, the relationship was inversed, with the regional scale of action serving to mobilize national political actors, in particular the country's president, Charles Taylor. Furthermore, it was a driving force in the structuration of women's movements. Indeed, as the conflict became regional, women's associations developed a network of peace activists from Liberia, Sierra Leone and Guinea: the Mano River Union Women Peace Network (MARWOPNET), which was created in May 2000. In both cases, the international level served as a resource. In Liberia, women called for international attention. For instance, in a statement read in Akosombo in June 2003, Theresa Leigh-Sherman, member of the MARWOPNET, claimed that 'We, the women of Liberia, hasten to alert the world of the urgent, catastrophic situation occurring in our country. ${ }^{24}$ Needless to say, those different scales interplay as, for instance, international donors often funded regional meetings.

The third context examines norms of action. Resolution 1325 provided a powerful normative framework for women's collective action in conflict and post-conflict settings. Indeed, in Liberia, the resolution was explicitly mentioned in the 2003 Golden Tulip Declaration, which set forth women's recommendations. In Burundi, it is interesting to note that, even though the resolution was adopted immediately following the Arusha negotiations, Burundian women were widely (and inaccurately) seen as having played a crucial role in its adoption. ${ }^{25}$ Yet the international 'Women, peace and security' framework coincided in many respects with the way in which 'women negotiated a symbolic space for themselves as public change agents'. ${ }^{26}$ Indeed, in both countries, women employed the same normative categories. These ranged from their role as mother/care-taker ('Our children are dying', ${ }^{27}$ 'Every woman is dedicated to give life, thus has to do everything she can, in every circumstance, to protect life ${ }^{28}$ ) to their status as victims and neutral agents ('Let's not speak about politics, let's just

\footnotetext{
${ }^{23}$ Sabine Sabimbona participated at the All-Party Burundi Women's Peace Conference. Elected as a Member of the Parliament in 1998, she was one of two women Members of Parliament who participated in the Arusha peace negotiations.

${ }^{24}$ Moses M. Zangar, 'Liberian Women Cry Out for Peace', The Perspective, 11 June 2003, in Liberian Women Peacemakers, African Women and Peace Support Group, quote at p. 49.

${ }^{25}$ Interview with Christine Ntaguvirumugara (present in Arusha on behalf of the presidency of CAFOB and a former Member of Parliament elected in 2005), Bujumbura, 25 July 2012.

${ }^{26}$ Colleen Elizabeth Kelley and Anna L. Eblen, Women Who Speak for Peace (Lanham, Md, USA: Rowman \& Littlefield, 2002), 197-8.

27 Pray the Devil Back to Hell. Directed by Gini Reticker. US: Balcony Releasing, 2008. https://archive.org/details/PrayTheDevilBackToHell (accessed July 5th, 2013).

${ }^{28}$ Sabine Sabimbona in Engendering Peace: Reflections on the Burundi Peace Process, Enid de Silva Burke, Jennifer Klot and Ikaweba Bunting (Nairobi: UNIFEM, 2001), quote at p. 30.
} 
speak about peace' ${ }^{29}$; 'Women are without ethnic belonging, all are victims' ${ }^{30}$ ). But if there is a coincidence between global norms and local strategic representations, what are the mechanisms that drive the hybridization of women's movements? How do women's movements cooperate with the UN to promote women's participation in peace negotiations?

\section{The UN political 'soft touch'}

'We cannot expect women to do all this alone. Their efforts must be recognized, valued and supported. To build peace and contribute to the rebuilding of their countries, women need resources, skills, authority. ${ }^{31}$ As this quotation indicates, the UN conceived the role of external actors as filling the gap between women's desire to act and their concrete capacity to foster social and political change. UN agencies would act to facilitate women's action in support of peace by providing them with social and material resources. Yet this 'soft touch' is not neutral; it has social and political effects.

As we have seen above, UN agencies have helped women's movements establish large networks. The international community represented a key ingredient in the success of the regional MARWOPNET network, for example, providing material resources and fora for communication via various mechanisms. Similar to those established in Burundi, they included an awareness-raising campaign, technical training, capacity building and so on. Furthermore, UN agencies offered social spaces where women from diverse religious, ethnic, social and political backgrounds could meet: 'We facilitated meetings between women without pushing ourselves forward. [...] UNIFEM appeared neutral, without political interest: it was easier to make women join together at our place. Because at this time, there were important ethnic divisions.' ${ }^{32}$ They also provided women's movements with useful contacts among regional decision-makers, mediators, representatives of the international community, negotiating parties and local women in Arusha and Accra. Finally, UN agencies specifically supported the participation of women leaders in peace negotiations by funding trips, reporting the event, providing financial and logistical support and organizing parallel conferences.

This support, which contributed to the professionalization of women's movements and their participation in peace negotiations, also produced social effects, particularly to the degree that it promoted the emergence of a generation of women leaders. Indeed, the UN provided gender and leadership expertise to some women (mostly drawn from the elite) to help them acquire the skills necessary for leading movements and expressing their claims in the vocabulary of international standardized criteria during negotiations. As Veronika Fuest has observed, in Liberia 'Many, if not all, leaders have capitalized on the training they have received in workshops and on the cultural and social capital they have gained as participants at international conferences. ${ }^{33}$

UN support does not consist in a linear process: women's experiences in Liberia and Burundi have also served to establish women's participation in peace negotiations as an international best practice. Women's contributions have been applauded by the international community. As Graça Machel, a human rights activist and former wife of Nelson Mandela, has noted, 'The negotiators of peace in Burundi are showing the world that, even in the midst of heated debates, consensus on creating opportunities for women to assume their rightful roles as

\footnotetext{
29 Pray the Devil Back to Hell.

${ }^{30}$ Sabine Sabimbona in Engendering Peace, Enid de Silva Burke, Jennifer Klot and Ikaweba Bunting, quote at p. 29.

${ }^{31}$ Ellen Johnson Sirleaf and Elizabeth Rehn, Women, War, and Peace, 1.

32 Interview with Spès Rusuku (Finance Associate, UN Women), Bujumbura, 14 August 2012.

33 Veronika Fuest, 'Liberia's Women Acting for Peace: Collective Action in a War-Affected Country', in Movers and Shakers: Social Movements in Africa, ed. Stephen Ellis and Ineke van Kessel (Leiden; Boston, Mass., 2009), 114-137, quote at p. 133.
} 
shapers and beneficiaries of a new society can be an area of universal agreement.' 34 International cooperation among various organizations and individuals has also been praised. They have included the UNHCR, UNIFEM, the African NGO Femmes Africa Solidarite (FAS), the Mwalimus Nyerere Foundation (MNF), the women of Burundi and other UN agencies and NGOs. ${ }^{35}$ These much-lauded experiences have stimulated and informed international support for women's participation in peace negotiations, particularly by encouraging that a gendered perspective be brought to bear in order to improve the quality of peace agreements. ${ }^{36}$ The need to overcome political cleavages is one of the most frequently cited lessons learned in UN reports. ${ }^{37}$ The political effects of (supposedly neutral) UN support can thus not be denied. As one UNIFEM employee confirmed: 'Women lobbied and sent a strong delegation. We supported them even if it was political. But there is necessarily a feminist component in the field of women's rights. What remains clear is that to appear neutral is an essential condition to rapprochement. 38

The cases of Burundi and Liberia show singular trajectories along three dimensions: various temporalities of international support to women's movements; particular logics of scale mobilisation by women organised in movements and networks; and different influence of global norms on women's strategic social representations (especially those referring to "Women, Peace, and Security" framework). Nevertheless, in both cases, international support to women's participation in peace negotiation follows the same trend: a circulation of norms and practices across space (between international, regional, national and local scales) and time (between the contextualised experience of women's participation and its retrospective making in a best practice by international actors).

\section{Impacting peace negotiations: a 'parallel' diplomacy ${ }^{39}$}

I now turn to consider women's concrete experience of peace negotiations. I focus less on the levels of actors, be they labelled 'international' or 'local', than on discourses and practices that emerge from their interactions in the process of negotiation - mainly between women part of the delegation, state's representatives and male politicians, and international organisations' officials and consultants. How has cooperation between UN agencies and women's movements impacted women's experiences of peace negotiations and how has it helped shape their identity as a 'societal actor'?

Examining women's participation in peace negotiations means going beyond official and formal structures, where they have relatively little say. For my purposes, there is little to be gained from distinguishing between formal/informal and official/unofficial structures and practices. Rather, I shall consider how these structures and practices relate to one another. More

\footnotetext{
34 Enid de Silva Burke, Jennifer Klot and Ikaweba Bunting, Engendering Peace, 42.

35 Erin K. Baines, A Practical Guide to Empowerment, 13.

36 See UNIFEM. Women's Participation, 24.

37 See Erin K. Baines, A Practical Guide to Empowerment, 14.

${ }^{38}$ Interview with Spès Rusuku (Finance associate, UN Women), Bujumbura, 14 August 2012.

39 This expression, which I translated into English, is employed by Catherine Mabobori in reference to women's practices in Arusha ('Place aux femmes', quote at p. 44). In an interview I conducted with her in March 2014, she explained that she was referring to the concept of 'track-two diplomacy' as a way of influencing negotiations by using more informal lobbying methods while occupying a non-official position, outside the government power structure. The use of scholarly concepts serves to illustrate the various sites of socialisation (academic, activist and political) influencing the trajectories of women leaders. However, as I explain in this section, I have decided to retain the expression 'parallel' diplomacy rather than contrast 'track-one'/'track-two' diplomacy, informal/formal channels of influence and official/unofficial positions. This expression is also employed by Fabienne Hara in 'Chapter 7: Burundi. A Case of Parallel Diplomacy' in the case of Burundian peace negotiations but it tends to assimilate a particular form of diplomacy (a practice), with the kind of actors studied, here non-state actors.
} 
specifically, I argue that women's experiences can be described as a 'parallel' form of diplomacy. By this, I am referring to all of the practices employed by women to influence the process and outcome of negotiations alongside formal channels and official peace talks. This form of influence impacts the dynamics rather than the structure of peace negotiations.

\section{Continuity between formal and informal action channels}

In Liberia as in Burundi, while women were granted observer status, they were denied full participation and thus the right to speak or vote. However, they invented and/or took advantage of other channels to influence peace negotiations. After being removed from peace negotiations in late 1998, women in Burundi continued to protest in the halls, organize information sessions to influence the outcome of the various commissions and lobby political figures. Similarly, as the documentary film Pray the Devil Back to Hell vividly shows in the case of Liberia, women gathered outside the conference room, blocking access to the negotiating parties and forcing them to speak. Outside the site of negotiations, they also demonstrated and organized in Accra, in refugee camps, in churches and on the airfield adjoining the Monrovia fish market. Nevertheless, their space of influence cannot be reduced to informal and unofficial places; international support also allowed them to establish parallel official spaces of discussion. In early 2000, closed-door sessions were held in Arusha between the seven Burundian women of the delegation and the international mediator, Nelson Mandela, to discuss gender issues.

The modes of action employed by women ranged from maintaining a presence at peace negotiations, to strategic and personal lobbying, 'backroom diplomacy' and parallel conferences. ${ }^{40}$ Women leaders in Burundi, for instance, targeted regional political leaders on the issue of the embargo. They used regional meetings supported by the UN, informal lobbied or organized themselves into delegations to address the embargo and their presence at peace talks. In 1999, the embargo was lifted, a decision interpreted by many observers as a victory on the part of the women's lobby, with support from powerful women leaders in the region - in particular, Speciosa Kazibwe and Aloisea Inyumba. Liberian women relied upon a more unofficial method of lobbying - 'backroom diplomacy' - entering into contact with leaders of the rebellion outside Liberia, although in doing so they exposed themselves to virulent attacks on the part of the government. In both cases, thanks to the international support they enjoyed, what's more, they were able to organize and participate in parallel women's conferences. These included the All-Party Burundi Women's Peace Conference, which was held in Arusha on 1720 July 2000 and brought together 50 Burundian women delegates and observers. With support from UNIFEM, Liberian women held a one-day Consultative and Strategic Planning Meeting under the chairmanship of Ruth Sando Perry to which the representatives of the various Liberian women's organisations were invited. This took place on 15 August 2003 at the Golden Tulip Hotel in Accra. Both conferences issued major declarations. These parallel spaces played a decisive role in winning a place for women's recommendations in the final peace accord.

To conclude, women used both informal and formal channels and were active in official and unofficial spaces alike. A common trend, however, is to be underscored: with strong support from the UN, women tended in both cases to formalize their influence and put it on an official footing, even though it had been exercised via 'parallel' diplomacy. This form of diplomacy should thus not be assimilated with the kind of actor who intervene, here societal actors, but analysed as a practice, shaped by cooperation between women, who were denied the right to speak at the negotiation table and the UN, who saw in their support a way to influence

\footnotetext{
40 With the exception of conference proceedings, final declarations and press articles, I was able to gather few written sources. Given the particular channels that were employed, most of my data is supplied by interviews and videos. See Gaëlle Le Goff, L'influence des organisations non gouvernementales sur la négociation de quelques instruments internationaux, Thesis submitted to the faculty of Graduate Studies and Research in partial fulfilment of the requirements of the degree of Master, (Montreal, MacGill University), 107-113. The author analyses unregulated channels of NGO influence: strategic, information and training meetings and service provision.
} 
the course of peace negotiations. The question remains whether this 'parallel' diplomacy has a concrete impact on the negotiation, considering its dynamics as well as its structure.

\section{Influencing the dynamics rather than the structure of negotiation}

The 'structure of negotiation' refers to institutionalized practices, such as the rules of voting and negotiation, the status of parties and the constraints on negotiation. The 'dynamics of negotiation', by contrast, refers to the psychosocial environment, the methods employed, the formation of ad hoc coalitions and groups and the course of political bargaining. ${ }^{41}$ Employing certain aspects of William Zartman's typology of multilateral negotiations, ${ }^{42}$ I argue that the participation of women in peace negotiations transformed the dynamics of the peace negotiations under consideration here in several ways and to varying degrees.

First of all, women were not granted observer status overnight: conquering this status was the outcome of a long, uncertain struggle. Moreover, it was exclusively granted on behalf of women in official negotiations, in contrast to parallel conferences, where they were able to represent political parties or refugee communities. In seeking observer status, however, women sought above all to achieve recognition as a political actor in their own right rather than use this newly 'official status' to influence peace negotiations. In Burundi and Liberia, the temporary or permanent participation of women - whether as a non-accredited delegation, observers or full participants; whether to represent women's group, civil society or political parties - was a source of intense debate among participants. For the parties to official peace negotiations, the addition of a new party in itself presented issues. In Burundi, the mediating team put the issue on the table on several occasions in the course of Arusha II (20-29 July 1998) and Arusha IV (Jan. 1999). Each time, however, the proposal was roundly refused. Women were only granted temporary observer status in January 2000. At the Liberian peace negotiations, MARWOPNET and WIPNET were granted observer status but without the power to speak or vote. However, due to the critical mediating role that MARWOPNET played among the various factions involved in the peace talks, it was included among the signatories witnessing the agreement.

Second, their participation revealed the complex interrelations between various levels of negotiation, which was all the greater given that 'women' do not constitute a homogeneous category. Women had to negotiate with parties who had often denied them full participation on the grounds that they might represent vested ethnic interests, particularly those of political parties or the female elite. What's more, in order to develop a clear, common position, they first had to negotiate among themselves within the delegation and report to women activists who remained in the country. The discussions that took place concerning the embargo clearly illustrate this point: while those representing Burundian women living in the country (three Hutu and three Tutsi) insisted on an end to the embargo, the seventh member of the nonaccredited women's delegation, Emilienne Minani ${ }^{43}$ - a resident of Kenya representing women from the diaspora - favoured regional economic sanctions. Finally, due to the support they enjoyed from powerful women in the region, women representing those living in the country succeeded in imposing their position on Emilienne Minani. The case was different for Liberia: there, women were unable to reach a common position on the issue of sexual violence, which was ultimately left out of the peace accord and ceasefires. ${ }^{44}$

\footnotetext{
41 Petiteville and Placidi, Négociations internationales, 22-3.

42 Zartman, Processes of International Negotiation Project, and International Institute for Applied Systems Analysis, International multilateral negotiation.

${ }^{43}$ Emilienne Minani was also observer at the All-Party Burundi Women's Peace Conference and former Minister of Social Affairs in President Cyprien Ntaryamira's government.

${ }^{44}$ On divisions among Liberian women in regards to the issue of rape, see Fuest, Movers and Shakers, 126-35.
} 
Third, women transformed the negotiating environment. According to Catherine Mabobori, the women's mobilization 'has had a catalyst role on the rhythm of negotiations. Women played a very important role in hailing negotiators and persuading them to leave the field of power-sharing to focus on the public interest, in particular in order to put an end to the fighting. ${ }^{45}$ The situation was similar in Accra. As chief mediator and former Nigerian president General Abubakar remarked: 'I found an ally in women', explaining that they moved from one delegate to another, urging them to negotiate. As Liberian women delegates recount in the documentary film, Pray the Devil Back to Hell, the peace talks were going nowhere. Delegates behaved as if they were on holiday, taking full advantage of this break from the fighting to relax in their luxurious accommodations. In response, women decided to join arms and block the delegates inside the conference room, depriving them of food and water until an agreement was signed. The 'happy and gay' atmosphere that had hitherto prevailed became 'more serious and sober'. Women had succeeded in realizing their aim: their tactics had produced 'a real peace talk, not a circus'. ${ }^{46}$

Last but not least, women expanded the peace negotiation agenda to encompass new issues. Gender or women 's issues concerned equal participation in decision-making, protection and women's rights, special needs, the empowerment of women leaders and, in the case of Liberia, fostering links with UN agencies, such as UNIFEM. The inclusion of these issues has made peace accords more complex and required the intervention of external gender experts, such as those of UNIFEM or international consultants (Carolyn McAskie and Ruth Perry ${ }^{47}$ in Burundi). But while most of the recommendations elaborated at women's conferences and the special sessions held with mediators may be described as gender sensitive, some of these issues were already on the table in official discussions: the repatriation of refugees, an end to fighting, HIV/AIDS, transition and democracy (Table 1).

\footnotetext{
${ }^{45}$ Catherine Mabobori in 'Place aux femmes', quote at p. 46. Also in this case, it is likely that she might be referring, though only implicitly, to the Brian Hocking's concept of 'catalytic diplomacy', defined as the 'growing symbiosis between the activities of state and non-state representatives'. See 'Catalytic Diplomacy: Beyond 'Newness' and 'Decline', Innovation in Diplomatic Practice, ed. Jan Melissen (Basingstoke, Macmillan, 1999), 21-42, quote at p. 34.

46 Pray the Devil Back to Hell.

47 Ruth Perry was appointed Head of the Council of State in 1996-1997. She was also long active as a member of women's peace organisations and co-led the delegation of 8, which represented the accredited women's group at the 2003 Accra conference.
} 
Table 1. Women's recommendations elaborated in parallel conferences and special sessions

\begin{tabular}{|c|c|c|}
\hline Liberia & & ndi \\
\hline $\begin{array}{lr}\text { The Golden } & \text { Tulip } \\
\text { Declaration }(2003)^{48} \\
\text { - 'Greater participation of } \\
\text { women in peace keeping } \\
\text { missions'; } \\
\text { - 'Women r leaders', } \\
\text { 'Recognition r and } \\
\text { empowerment } \\
\text { delegates'; } \\
\text { - HIV-AIDS; } \\
\text { - Contacts with donor } \\
\text { agencies for future } \\
\text { programmes; r } \\
\text { - Cooperation } \\
\text { UNIFEM. }\end{array}$ & $\begin{array}{l}\text { Final declaration of the } \\
\text { All-Party Women's } \\
\text { Conference }(2000)^{49} \\
\text { - Equal participation in } \\
\text { decision-making; } \\
\text { - Land ownership rights; } \\
\text { - End to impunity on } \\
\text { - sexual crimes; } \\
\text { - Women's rights. }\end{array}$ & $\begin{array}{l}\text { Women's recommendations to } \\
\text { the Arusha peace accord } \\
(2000)^{50} \\
\text { - Equality between men and } \\
\text { women, parity, the struggle } \\
\text { against discrimination; } \\
\text { - Crimes against women and } \\
\text { children, rape, protection of } \\
\text { women and children; } \\
\text { - Special needs, health, } \\
\text { HIV/AIDS; } \\
\text { - Quota of } 30 \% \text { women's } \\
\text { representation in political } \\
\text { and administrative structures. }\end{array}$ \\
\hline
\end{tabular}

The cases of Liberia and Burundi share very similar trajectories of women's participation in peace negotiations, navigating between official and unofficial spaces, using formal and informal channels of action. This 'parallel' form of diplomacy influenced the dynamics of negotiations in several similar ways but had nonetheless contextualised effects on post-war women's movements.

\section{Conclusions. Identity politics: the making of a political actor}

Since women's delegations were not allowed permanent or full participant status in negotiations, women's participation in peace negotiations has not changed their rules or structure. Indeed, in regards to women, the peace accords only included vague, general recommendations, such as 'equality between women and men', ${ }^{51}$ rather than quantified ones (e.g., quotas). In recognition of this partial success, the UN has pushed for the standardization and routinization of women's participation in peace negotiations. ${ }^{52}$ In doing so, it seeks to allow women - whose efforts are too often focused on securing the right to participate in negotiations - to concentrate on promoting particular issues or contributions. Yet women's struggle to make their presence felt in peace talks was above all a fight to win recognition for themselves as political actors. More problematic is the notion that membership in a social category constitutes a cause for action - that is, the presumption that women's demands consist only of gender issues. Rather, their social identity as women should be studied as a political process of identity formation. Though often described as 'social' or 'volunteer' activities, organizing women's movements, demanding representation on behalf of women and building consensus and trust are thoroughly political activities.

\footnotetext{
48 The Golden Tulip Declaration of Liberian Women Attending the Peace Talks in Accra. Accra. 15 March 2003.

${ }^{49}$ Proceedings of the All-Party Burundi Women's Peace Conference: 17-20 July 2000, Arusha, Tanzania. Sponsored by UNIFEM and Mwalimu Nyerere Foundation, ABANTU for Development for the Regional Office for East, Central, and Horn of Africa, United Nations Development Fund for Women (UNIFEM, 2001).

50 'Propositions formulées par les femmes aux fins du projet d'Accord d'Arusha pour la paix et la réconciliation au Burundi', in Engendering Peace, Enid de Silva Burke, Jennifer Klot and Ikaweba Bunting.

${ }^{51}$ Arusha Peace and Reconciliation Agreement for Burundi. Arusha. 28 August 2000, 17.

52 See UNIFEM. Women's Participation, 10.
} 
Furthermore, in a context in which they were denied full access to peace negotiations, assuming assigned social roles as 'women' contributed to politicizing their activities. As Annalise Moser has observed, women strategically employ stereotyped gender roles: 'Women [...] capitalize on the commonly held images of women as peace-makers, as mothers who are both nurturers and arbitrators. ${ }^{53}$ Or, as Catherine Mabobori puts it: 'Had we cried, what was the problem? After all, the end justifies the means. Men use their arms to fight; we use our heart to struggle. ${ }^{54}$ As postmodernist feminists have shown, gender identity should not be taken as a point of departure but rather as a construct formalized through a matrix of habits, practices and discourses. ${ }^{55}$ Women's participation in peace negotiations may thus also be analysed as an interactional process of identity formation in which a particular group - women - is isolated and a set of characteristics is assigned to them.

Finally, women's participation in peace negotiations has shaped the discourses and practices of subsequent battles. Several of the issues addressed in the course of peace talks have come to the forefront of women's movements in post-conflict settings, including the right to land ownership and inheritance, equal participation in decision-making and sexual violence. ${ }^{56}$ One cannot deny the role played by the UN in providing women with resources to navigate the power structure. Women's declarations (e.g., the Golden Tulip Declaration) thus explicitly recognized the need to foster cooperation between women and the UN, especially UNIFEM/UN Women. ${ }^{57}$ While it would be an exaggeration to claim that it was the sole factor, cooperation between the UN and women's movements played a crucial role in politicizing women's collective action by providing important material and political resources and enhancing their visibility. These interactions have contributed to the 'political awakening, ${ }^{58}$ of a certain class of women. The challenge, however, 'is not only to open the political space, but also to create a strong public constituency that gives credibility to their demands. ${ }^{59}$

Concluding on theoretical and methodological aspects, this study brings us to think peace negotiations in a relational and dynamic way. Going back to the discussion on the 'local', this article has indeed shown that the 'local' refers to multiple units of analysis: the context (Burundi and Liberia constituting different 'locals'); the level (in opposition to 'global') or scale (like international, regional and national); and the space where everyday practices take place (negotiation as a political site where identities and strategies are redefined). Hence, I think it should be further researched less as a normative stance - such as a form of resistance offering 'an extrainstitutional politics of contestation that puts checks and balances on an existing system' 60 - than as a sociological unit from which to 'conceptualize more efficiently social dynamics produced by unique mechanisms which, however, by taking place in local configurations, diverse by the nature of their relational forms, produce important differentiations'. ${ }^{61}$

53 Annalise Moser, Women Building Peace and Preventing Sexual Violence in Conflict-Affected Contexts: A Review of Community-Based Approaches (New York: UNIFEM, October 2007), 18.

${ }^{54}$ Catherine Mabobori in 'Place aux femmes', quote at p. 45.

55 See Jill Steans, Gender and International Relations: An Introduction, 1 vol. (Cambridge, United Kingdom: Polity Press, 1998).

56 For example, the Burundian Constitution of 2005 includes the main women's recommendation of Arusha: a quota guaranteeing at least 30\% representation of women in elective positions. In Liberia, women's movements have acted as a watchdog of state implementation of peace accords (Pray the Devil Back to Hell).

57 The Golden Tulip Declaration of Liberian Women Attending the Peace Talks in Accra. Accra. 15 March 2003.

58 Catherine Mabobori in 'Place aux femmes', quote at p. 46.

59 Anderlini, Women Building Peace, 63.

60 Oliver Richmond and Audra Mitchell, Hybrid Forms of Peace, 304.

61 Jacques Revel (ed.), Jeux d'échelles : la micro-analyse à l'expérience (Paris : Gallimard, 1996), 139. 


\begin{abstract}
Drawing upon the cases of Burundi and Liberia, this paper studies cooperation between women and UN agencies to promote and formalise women's participation in peace negotiations. Ever since UNSCR 1325, the UN has supported women's efforts to participate in peace negotiations and more broadly promoted the inclusion of societal actors. However - neither in Burundi and Liberia, nor in general - have women been officially recognized as full participants. Given their outsider position, how do women's movements and delegations, in cooperation with UN agencies, shape the structure and dynamics of peace negotiations and influence their outcome? I argue that cooperation between women and UN agencies produces a 'parallel' form of diplomacy via the range of practices employed by women alongside official and formal peace talks. Despite their unofficial character, these practices nevertheless play a significant role in framing the course of peace negotiations.
\end{abstract}

Keywords: women's participation; peace negotiation; 'parallel' diplomacy; United Nations; Burundi; Liberia

\title{
Résumé
}

À partir des cas du Burundi et du Libéria, cet article étudie la coopération entre les femmes et les agences des Nations unies pour promouvoir et formaliser leur participation aux négociations de paix. Depuis la résolution 1325 du Conseil de sécurité des Nations unies, les agences des Nations unies soutiennent les efforts des femmes pour participer aux négociations de paix. Néanmoins, lorsque les femmes sont présentes, en aucun cas elles ne sont officiellement reconnues comme des participantes à part entière ; elles ont le statut d'observatrices, elles font pression sur les négociations formelles ou mènent des conférences parallèles. Ainsi, comment les mouvements et les délégations des femmes, en lien avec les agences des Nations Unies, façonnent-ils la structure et la dynamique des négociations de paix et influencent-ils leurs résultats? En s'appuyant sur des enquêtes de terrain menées au Burundi, des données d'archives de l'ONU, des entretiens et diverses sources audiovisuelles, l'article défend l'argument selon lequel la coopération entre les femmes et les agences des Nations unies produit une forme de diplomatie «parallèle »; terme faisant référence à une gamme de pratiques utilisées par les femmes à côté des pourparlers officiels de paix, qui constituent néanmoins des canaux importants dans le cadre des négociations de paix au Libéria et au Burundi.

Mots clés : participation des femmes ; négociations de paix ; diplomatie «parallèle »; Nations unies; Burundi ; Libéria 